\title{
Morality and State in the Fichtean Political Philosophy
}

\author{
Moralidad y Estado en la filosofía \\ política de Fichte
}

\author{
Hector Oscar Arrese Igor ${ }^{1}$ \\ Centro de Investigaciones Filosóficas, CONICET (Argentina)
}

Recibido: 28-08-17

Aprobado: 28-02-18

\begin{abstract}
The philosophy of history of 1804 and 1805 enables Fichte to place his natural right, developed previously at Jena, against a diachronic background. This means that Fichte does not reason merely synchronically from a timeless conception of society and state. From a synchronic viewpoint, Fichte cannot solve the problem of the control of political power because he has to draw on the assumption of a virtuous ephorate. This assumption is not consistent with the Fichtean ideal of a philosophy of right completely independent from moral considerations. Thus, the control of government is possible only if at least a group of citizens can go beyond the mere rational egoism. This new temporal conception of the state leads Fichte to think that the problems of consistency of his theory of Jena are unavoidable, given that a society integrated by egoist individuals cannot be sustained. However, his later philosophy of history enables Fichte to state the inexorable annihilation of this type of community and gives place to an ensuing epoch, when citizens are not self-interested anymore.
\end{abstract}

Key-words: Fichte, Right, Egoism, Citizenship, History.

\footnotetext{
${ }^{1}$ (harreseigor@gmail.com) Investigador Adjunto del Centro de Investigaciones Filosóficas, Consejo Nacional de Investigaciones Científicas y Técnicas (Argentina). Se desempeña como Profesor Asociado Ordinario de Filosofía de los Siglos XIX y XX en la Universidad Pedagógica Nacional y Profesor Titular Ordinario de Filosofía Social en la Universidad Nacional de La Plata. Ha sido becario del Servicio Alemán de Intercambio Académico (Deutscher Akademiker Austauschdientst) en las universidades de Halle y Heidelberg (República Federal de Alemania). Ha publicado números artículos sobre temas de ética, filosofía política, filosofía social y filosofía del derecho, en los ámbitos del idealismo alemán y el neokantismo de Marburg. Es autor del libro Derecho, Intersubjetividad y Justicia (Buenos Aires, UNSAM Edita, 2016).
} 


\section{Resumen}

La filosofía de la historia de 1804 y 1805 permite a Fichte ubicar a su derecho natural, desarrollado previamente en Jena, en el marco de un trasfondo diacrónico. Esto significa que Fichte no razona meramente de modo sincrónico, es decir a partir de una concepción atemporal de la sociedad y el Estado. Desde un punto de vista sincrónico, Fichte no puede resolver el problema del control del poder político, porque debe recurrir al supuesto de un eforato virtuoso. Este supuesto no es consistente con el ideal fichteano de una filosofía del derecho completamente independiente de consideraciones morales. Por lo tanto, el control del gobierno es posible solamente si por lo menos un grupo de ciudadanos puede ir más allá del mero egoísmo racional. Esta concepción temporal nueva del Estado lleva a Fichte a pensar que los problemas de consistencia de esta teoría son inevitables, dado que una sociedad integrada por individuos egoístas no es sostenible. Sin embargo, esta filosofía tardía de la historia permite a Fichte afirmar la aniquilación inexorable de este tipo de comunidad y da lugar a la época siguiente, en la que los ciudadanos ya no son auto-interesados.

Palabras-clave: Fichte, Derecho, Egoismo, Ciudadania, Historia.

During his time at Jena, Fichte tries to elaborate a Theory of Right, without drawing on moral assumptions, in line with the Kantian idea of a form of government which could be applicable even to a people of devils. This implies that Fichte builds his theory on the assumption of the universal egoism. ${ }^{2}$ The reason for this project lies in the Fichtean search for the conditions of selfconsciousness, which is understood as the attribution to oneself of the capability to act in the sensible world. ${ }^{3}$

Furthermore, Fichte explains self-consciousness from the recognition of the other, because he cannot do so from the relation between subject and object, which is characteristic of the relation of knowledge. ${ }^{4}$ The type of intersubjective

2 "(...) love ourself above all else and love our fellow citizens for our own sake", Johann Gottlieb Fichte, Foundations of Natural Right, trans. Michael Baur, ed. Frederick Neuhouser, New York, Cambridge University Press, 2000, p. 237; "liebe dich selbst über alles, und deine Mitbürger um dein selbst willen"; Johann Gottlieb Fichte, Grundlage des Naturrechts nach Prinzipien der Wissenschaftslehre, Jena and Leipzig, Christian Ernst Gabler, 1796/179. It is quoted according to Johann Gottlieb Fichte: Gesamtausgabe der Bayerischen Akademie der Wissenschaften, ed. Reinhard Lauth and Hans Jacob, Stuttgart-Bad Cannstatt, Frommann Verlag, Günther Holzboog, 1966, with the volume and page number. Here: GA, I, 4, § 20, p. 69.

3 "If a rational being is to posit itself, then it must ascribe to itself an activity whose ultimate ground lies purely and simply within itself", Fichte, Foundations of Natural Right, 18; "Soll ein Vernunftwesen sich als solches setzen, so muss es sich eine Thätigkeit zuschreiben, deren letzter Grund schlechthin in ihm selbst liege"; Fichte, Grundlage des Naturrechts ..., GA, I, 3, § 1, p. 329.

${ }^{4}$ Jürgen Stolzenberg, "Fichtes Begriff des praktischen Selbstbewusstseins" (in Wolfram Hogrebe, Fichtes Wissenschaftslehre. 1794. Philosophische Resonanzen, Frankfurt am Main, Suhrkamp, 1995), p. 80. 
relationship that makes self-consciousness possible is that in which the other summons the I to free action, namely, to self-determination. ${ }^{5}$ Thus, the other conveys to the I the concept that he or she has of him or her, which is the idea of a rational being. But this communication is possible only if the other acts in a certain way, that is, according to some formal conditions. The most important of these rules consists of the delimitation of a space of action identical for the I and the other. The principle of right, as Fichte names this fundamental rule, implies that the I is free to respond or not to the summons of the other because otherwise the I would not retain his or her sphere of free actions, and that principle would not be valid. ${ }^{6}$

Given that the I remains free to respect the sphere of actions of the other or not to do so, it remains definitely open to the possibility that the I impinges upon the capability of agency of the other and eventually the conditions of his or her self-consciousness. As a result, Fichte deems it necessary to introduce a third instance that must settle the conflicts that may arise between the I and the other, which is the state. In order for this political community to fulfil its function, it must be designed as a set of rules that are meant to control egoists and not virtuous citizens so that they do not put in danger the freedom of the others. This is the aim of the social contract, in all its levels and dimensions. For this reason, the property contract, which is the first moment of the civil contract, aims only at each citizen engaging in refraining to interfere in the sphere of actions of the others. ${ }^{7}$ In a second moment, Fichte suggests the necessity of complementing this first contract with the contract of protection, which requires the positive engagement in defending the citizen whose property is in danger. ${ }^{8}$

In order to give effect to the contract of protection, the citizens must enter in the contract of unification (Vereinigungsvertrag) to constitute themselves in a community. ${ }^{9}$ This requires, in turn, the signature of the contract of submission (Unterwerfungsvertrag), through which everyone engages in obeying the government as subjects. ${ }^{10}$ As a consequence, everyone accepts in advance paying the penalties that they would receive in the case of infringing upon the former contracts in terms of the contract of expiation (Abbüssungsvertrag). ${ }^{11}$ In the following section, I will try to show that Fichte does not succeed in sustaining the project of a theory of right without taking into consideration the moral philosophy, but he must draw on moral assumptions in order to sustain the civil contract.

\footnotetext{
${ }^{5}$ Fichte, Grundlage des Naturrechts, GA, I, 3, § 3, p. 342.

${ }^{6}$ Fichte, Grundlage des Naturrechts, GA, I, 3, § 4, p. 358.

${ }^{7}$ Fichte, Grundlage des Naturrechts, GA, I, 4, § 17, p. 8.

${ }^{8}$ Fichte, Grundlage des Naturrechts, GA, I, 4, § 17, pp. 9-11.

${ }^{9}$ Fichte, Grundlage des Naturrechts, GA, I, 4, § 17, p. 15.

${ }^{10}$ Fichte, Grundlage des Naturrechts, GA, I, 4, § 17, p.17.

${ }^{11}$ Fichte, Grundlage des Naturrechts, GA, I, 4, § 20, p. 60.
} 


\section{The Control of the Government in the Natural Right of Jena}

The moral and psychological assumption of universal egoism leads Fichte to necessarily restrain popular participation in the government, thus taking a definitely anti-Rousseauian turn. ${ }^{12}$ The government must concentrate all the power in its hands and make impossible all forms of civil participation in the making of decisions that are relevant to common life because otherwise the people would fall into an inevitable social fragmentation and a war of all against all. This requirement is materialized by the submission contract, by virtue of which each citizen confines him or herself to the domestic and private dimension, limiting him or herself to fulfil the role allotted in the social division of labor as centrally planned by the state.

Nevertheless, the problem presented by this model of the exercise of power is the control of who makes the decisions. Fichte establishes the ephorate as a mediation to solve the task of monitoring who must control the citizens. ${ }^{13}$ The ephors do not have coercive power over the government, even though they can proclaim an interdict and call it to a popular assembly in order to submit the government to a political judgment. ${ }^{14}$ However, the ephorate must be composed of citizens chosen by their peers because of their virtues and wisdom (i.e., for not being egoists). The reason for that is that should the ephors be selfinterested, they would reproduce the problem of the control of the ephors, who, in turn, must control the government and must do so with the citizens. ${ }^{15}$ Here, Fichte finds one of the limits or blind spots of his theory because he must draw on ethical assumptions in order to build a theory that is meant to be independent of moral considerations.

These limitations acquire dramatic touches when Fichte must face the possibility that the ephors do not result in being as virtuous as expected and become corrupt themselves or are threatened by the government, because the armed forces must be only in the hands of the person who steers the state, according to the assumption of universal egoism. Fichte tries to solve this

\footnotetext{
${ }^{12}$ It is for this reason that Fichte achieves a republican synthesis of three moments. The first is a Rousseauian moment: the idea that the people are the supreme power and the origin of all power, whereby the general will is affirmed. In the second place, there is a Lockean moment, which appears in the criticism of the direct democracy as a form of despotism and the defense of the representative democracy. And finally, a Hobbesian moment can be found in the Fichtean Natural Right, that is, the unit of legislative, juridical, and executive powers, Alain Renaut, Le Système de Droit. Philosophie et droit dans la pensée de Fichte, Paris, Presses Universitaires de France, 1986, pp. 378-379).

${ }^{13}$ Fichte, Grundlage des Naturrechts, GA, I, 3, § 16, p. 441.

${ }_{14}$ Fichte, Grundlage des Naturrechts, GA, I, 3, § 16, p. 449

15 " $(\ldots)$ the kind of person who should become an ephor is one who has gained the attention and trust of the people (who, precisely in order to fulfill this sublime task of electing the ephors, will continuously notice their great and honest men)" (Fichte, Foundations of Natural Right, p. 159; "auf wen das Auge und das Zutrauen des Volks fällt, welches, gerade um dieser erhabenen Wahl willen, auf seine biederen und grossen Männer fortgehend aufmerken wird, derselbe wird Ephor"; Fichte, Grundlage des Naturrechts, GA, I, 3, § 16, p. 456).
} 
eventuality by resorting to the possibility that some citizens rebel against the authorities and the ephorate itself. These rebels are the "natural ephors", that is, citizens with a sense of justice that drives them to jeopardize their lives in order to preserve the common freedom and property. ${ }^{16}$ Furthermore, Fichte foresees an eventual result of this conflict, in which the same natural ephors are condemned as if they had become corrupted and merely seditious. This sentence will be absolutely supported by law, given that the natural ephors are, by definition, outside of the system. ${ }^{17}$

As in the case of the protection contract, Fichte is forced to draw again on normative and moral assumptions in order to maintain and give stability to the legal system. This juridical construction is meant to be morally neutral, even though it ultimately does not have enough internal mechanisms to preserve it in case the ephors become corrupted. In other words, the Fichtean theory needs mechanisms of popular participation that go beyond the mere meeting on occasion of an eventual political judgment to the government. Thus, I consider that, in such a case, the theory would acquire certain sustainability, given that the people are able to control the ephors and to intervene in case they become severely corrupted. On the other hand, as Hegel wisely remarks, only the regular participation of citizens in political life would make possible the development of the virtues and emotions which are necessary to participate in the popular assemblies in an eventual political judgment. ${ }^{18}$

Resuming the considerations of the former section, the Fichtean idea of education actually remains restricted to the familiar and domestic domain. For this reason, this idea of education reinforces the problem that the citizens live isolated among the political community, without cultivating the social bonds that make possible a shared political action.

I think that it would have been convenient if Fichte would nuance from the beginning the strength of his assumption of universal egoism in order to give place to the normative moral assumptions that are necessary to give stability to the contract of submission. Finally, this decision would have given more explicative power and an important proportion of consistency to his theory of natural right. Only in this way would the theory be able to give an account of the problem of the recognition of the other and therefore of self-consciousness. Later, in his text, The System of the Science of Right, written in 1812, Fichte will face this problem again, even though he will solve it in a very different way.

\footnotetext{
${ }^{16}$ Fichte, Grundlage des Naturrechts, GA, I, 3, § 16, p. 457.

${ }^{17}$ Fichte, Grundlage des Naturrechts, GA, I, 3, § 16, p. 458.

${ }^{18}$ Georg Wilhelm Friedrich Hegel, Über die wissenschaftlichen Behandlungsarten des Naturrechts, seine Stelle in der praktischen Philosophie und sein Verhältnis zu den positiven Rechtswissenschaften; in: Kritisches Journal der Philosophie, Bd. II, Part 2, [November/December] 1802, Part 3, [May/ June] 1803. Quoted according to the edition: G.W.F. Hegel: Werke in 20 Bänden; Frankfurt am Main, Suhrkamp Verlag 1970, Volume 2, 474.
}

Araucaria. Revista Iberoamericana de Filosofia, Política, Humanidades y Relaciones Internacionales, año $21, \mathrm{n}^{\circ} 41$. Primer semestre de 2019. Pp. 79-96. ISSN 1575-6823 e-ISSN 2340-2199 doi: 10.12795/araucaria.2019.i41.04 


\section{The State as a Condition of Morality}

Fichte seems to be aware of the aforementioned problems, given that in The System of the Science of Right, he reformulates from the beginning his previous conception of the relationship between right and ethics. In contrast to the natural right of Jena, Fichte in his later philosophy maintains that right has a mere propaedeutic function because it has the aim to protect each citizen's freedom so that it makes it possible the development of each subject and therefore paves the way to the reign of moral law. ${ }^{19}$

As Geismann rightly points out, this displacement from an amoral conception of right to a conception that puts it in the service of morality is consistent. From the background of the natural right of Jena, Fichte states that the principle of right has a hypothetical validity. This means that individuals must submit to the principle of right only if they want to enter into a legal community. As a consequence, this imperative does not have a binding character but is conceived as completely amoral. ${ }^{20}$ Therefore, the state remains at the service of the hazardous aim of establishing a legal community. That is the reason why the state is compatible with an indeterminate series of aims, among which is the service of morality.

In order to protect the conditions of morality, the right must guarantee the self-preservation of each individual in existence and his or her exercise of property rights. ${ }^{21}$ Taking into account the moral development of individuals, the right must guarantee them a reasonable quantity of time for leisure for them to be able to realize the supersensible aims of morality without the state interfering in their privacy. ${ }^{22}$ In Fichte's words: the state is the moral factual condition of morality (die sittliche faktische Bedingung der Sittlichkeit). ${ }^{23}$ However, the state cannot enforce moral freedom without falling into a despotic form of government. Instead, it must merely protect the space of freedom that the citizens need to pursue their moral aims. ${ }^{24}$ Meanwhile, it is not about the state being forced to fulfil this rather negative obligation, but it has to fulfil an additional positive obligation of designing an educational system that enables individuals to develop their moral capabilities. ${ }^{25}$

19 Johann Gottlieb Fichte, Das System der Rechtslehre, in Fichtes Sämtliche Werke, ed. Immanuel Hermann Fichte, Berlin, Walter de Gruyter, 1971, Volume X, 500-502.

20 „Georg Geismann, „Fichtes ,Aufhebung“ des Rechtsstaates“, Fichte- Studien. Band 3. Sozialphilosophie, Amsterdam, Atlanta: Editions Rodopi, 1991, pp. 86-117“.

${ }^{21}$ Fichte, Das System der Rechtslehre, p. 517.

${ }^{22}$ Fichte, Das System der Rechtslehre, p. 544.

${ }^{23}$ Fichte, Das System der Rechtslehre, p. 540.

${ }^{24}$ Fichte, Das System der Rechtslehre, p. 539.

${ }^{25}$ Fichte, Das System der Rechtslehre, pp. 540-542.

Araucaria. Revista Iberoamericana de Filosofía, Política, Humanidades y Relaciones Internacionales, año $21, \mathrm{n}^{\circ} 41$ Primer semestre de 2019. Pp. 79-96. ISSN 1575-6823 e-ISSN 2340-2199 doi: 10.12795/araucaria.2019.i41.04 
Geismann states that this moralizing conception of the state is authoritarian. ${ }^{26}$ This reactionary character is based upon the idea that the state does not only guarantee external freedom (as was the case in the natural right of Jena) but also the reign of inner or material liberty, i.e., the autonomy of citizens. Therefore, the state is legitimated to force those citizens who are not determining their will by the moral law. ${ }^{27}$ In other words, according to Geismann's interpretation, the state has the function to coerce the citizens to pursue a particular purpose, which is the realization of moral law. Furthermore, Geismann argues that this conception of the state is contradictory. The reason for that is that if the citizens are morally autonomous, they cannot accept that an external force coerces them to determine their will by the moral law. As a consequence, this moralizing conception of the state would destroy the same moral freedom it is meant to establish. ${ }^{28}$

It is the same case, argues Geismann, if we take into account the material aspect of freedom. On the one hand, the law cannot foresee the variety of actions that the subjects will realize in order to materialize the moral law, because the law contains only general indications. On the other hand, hazard or contingency plays a decisive role when putting into practice the moral aims. This role implies, in turn, that the courses of action performed necessarily will be affected by a series of unpredictable circumstances. Finally, the concrete courses of action that the citizens perform to materialize the moral aims could be involved in conflicts with each other, which implies that the law could not be applied in order to resolve them. ${ }^{29}$ Geismann states that the Fichtean theory leads to a "suppression of the state of right", because while centralizing all the power in the government, the latter remains excluded from the same law it passes. Therefore, the government that coerces the citizens to pursue the moral law must be morally perfect. ${ }^{30}$

Against Geismann's interpretation, Schottky argues that the Fichtean theory does not constitute a form of a moralizing despotism. ${ }^{31}$ In the first

\footnotetext{
${ }^{26}$ „Geismann, „Fichtes ,Aufhebung“ des Rechtsstaates“. This thesis is also developed in Manuel Jiménez-Redondo, "Fichte gegen Napoleon: Die zugrundeliegenden Ideen von Freiheit und Nation", Fichte-Studien. Band 44. Beiträge zur Geschichte und Systematik der Transzendentalphilosophie, ed. Marco Ivaldo, Leiden, Brill Rodopi and Hotei Publishing, 2017, pp. 190-208, 193-207 and Alois K. Soller, „Nationale Erziehung und sittliche Bestimmung“, Fichte-Studien, Band 2. Kosmopolitismus und Nationalidee, New York, Rodopi, 1990, p. 107.

${ }_{27}$ Geismann, „Fichtes ,Aufhebung“ des Rechtsstaates“, pp. 106-107.

28 Geismann, „Fichtes ,Aufhebung“ des Rechtsstaates“, p. 110.

${ }^{29}$ Geismann, „Fichtes ,Aufhebung“ des Rechtsstaates“, p. 111.

${ }^{30}$ Geismann, ,Fichtes ,Aufhebung“ des Rechtsstaates“, pp. 114, 117.

31 Siep argues too that the later Fichte remains faithful to the principles of the French Revolution, even though he leaves out the aspects referred to in the protection of the rights of the individual and emphasizes those which are related to the collective dimension of the nation; Ludwig Siep, "Revolution, Nation und Individuum in Fichtes philosophischer Entwicklung" in Fichte-Studien. Band 44. Beiträge zur Geschichte und Systematik der Transzendentalphilosophie, ed. Marco Ivaldo, Leiden: Brill Rodopi and Hotei Publishing, 2017, pp. 144, 150. On the other hand, Bloch remarks
} 
place, Schottky states that Fichte associates the coercion of the state only with the external use of freedom but never with the inner domain of the material or moral freedom. ${ }^{32}$ This association means that the state has the function to guarantee the factual conditions of morality, the first of which is the formal and external disposition of the citizens to fulfil the law, without caring about what its moral motives could be..$^{33}$ In respect to the development of morality, the Fichtean state has, at most, the function of establishing educative institutions. ${ }^{34}$ Therefore, from Schottky's viewpoint, the responsibility for one's own moral improvement remains in the hands of the citizen's free will. In the same context, Schottky retorts to Geismann that there is another reason for concluding that the Fichtean theory of the state does not imply a form of despotism. This reason is based upon the theory of popular control over the political power through the education of a critical citizenship. ${ }^{35}$ I agree with Schottky's argumentation, given that Fichte remains worried in his late philosophy about the problem of the popular control, which had remained unsolved in the natural right of the Jena period. I think it is important to consider the Fichtean argumentation with some detail.

In this context, Fichte resumes the theoretical problem that he has faced in his theory of the ephorate in the context of his Foundations of the Natural Right. The argument developed by Fichte can be reconstructed as follows. The people can coerce the ephorate in order to initiate a revolution with any motive, even in the case that this is illegitimated or unnecessary, because the power of coercion is possessed only by the government. Nevertheless, the government surely will use its power of coercion in order to submit the ephorate, as had actually happened with the Roman patricians. ${ }^{36}$ On the other hand, the ephorate in itself is not desirable because the ephors are chosen by the people and are at the service of the resolution of the assembly in the case of a political judgment. However, even though it is true that, from the formal viewpoint, the people's judgment is always in accordance with right, even when there is a judge that is above the people, not always is it so from the material viewpoint. This means

that Berliner Fichte defends a sort of "mystical democracy". Besides, Bloch argues that Fichte criticizes strongly every form of tyranny, inasmuch as he denounces Napoleon Bonaparte's policy of military conquest. According to Bloch, his criticism is applicable even to Hitler himself, opposing the Nazi appropriation of Fichte; Ernst Bloch, „Fichtes Reden an die deutsche Nation (1943)“, (in Werkausgabe. Band 11. Politische Messungen, Pestzeit, Vormärz, Frankfurt am Main, Suhrkamp, 1985), pp. 304, 309.

${ }^{32}$ Richard Schottky, „Rechtsstaat und Kulturstaat bei Fichte. Eine Erwiderung“, Fichte- Studien. Band 3. Sozialphilosophie, Amsterdam, Atlanta: Editions Rodopi, 1991, p. 142.

${ }^{33}$ Schottky, ,Rechtsstaat und Kulturstaat", pp. 143-144, 146.

${ }^{34}$ Schottky, ,Rechtsstaat und Kulturstaat", p. 145.

${ }^{35}$ Schottky, ,Rechtsstaat und Kulturstaat", p. 138.

${ }^{36}$ Fichte, Das System der Rechtslehre, p. 632; Allen Wood, "Fichte's Philosophy of Right and Ethics" (in The Cambridge Companion to Fichte, eds. Gunther Zöller and David James, Cambridge: Cambridge University Press, 2016), p. 186.

Araucaria. Revista Iberoamericana de Filosofía, Política, Humanidades y Relaciones Internacionales, año $21, \mathrm{n}^{\circ} 41$. Primer semestre de 2019. Pp. 79-96. ISSN 1575-6823 e-ISSN 2340-2199 doi: 10.12795/araucaria.2019.i41.04 
that in The System of the Science of Right, Fichte acknowledges that the people can give a wrong judgment, given that the political judgment is settled only by the vote of the majority. Thence, Fichte concludes that it is better to trust a selected group among the wisest rather than in a majority that God knows how it has been possible to gather. ${ }^{37}$

Fichte states that the ephorate is an institution that could exist among a morally bad or ignorant people. ${ }^{38}$ Nevertheless, the functions of the ephorate can be fulfilled rightly by a well-informed public. The government will take care not to contradict an educated people who will ask the government to give an account of its actions and will threaten the authority to call the whole people in the event that it does not listen to them. ${ }^{39}$

Therefore, Fichte states that the solution for the problem of the control of the government is the moral education of its citizenship. Thus, a critical citizenship with a vigilant attitude is the best corrective for a corrupt and unfair government. In this point, Fichte is in line at least partially with the republican tradition. ${ }^{40}$ In this text, Fichte disbelieves the existence of formal mechanisms that could make it possible that the best rule the community. On the one hand, if the government is a bad person, then he or she would not be willing to transfer the power to another person. On the other hand, if the government is a good person, then he or she will not deem that there is another person more apt to rule than him or herself and will resist passing power to another person. Finally, neither will the people be able to choose the best for the government because each citizen will believe in good faith that he or she is the best suited for the role. $^{41}$

Consequently, Fichte leaves the decision about who is the best of all and therefore is the one who will have to rule the community in the hands of the divine government of the world. The wisest must limit themselves to lead the people so that the necessary moral progress can be achieved in order to rule the state according to right. Meanwhile, it seems arbitrary and less compelling to put in the hands of the "divine government of the world" the solution of the right election of the government. I consider that the meaning of this expression has to do with what Fichte calls the "plan of the universe", that is, a progressive conception of history that culminates in the absolute state.

From James's viewpoint, Fichte conceives an idea of a plan of the universe in terms of a postulate of the practical reason. This implies that the necessity

${ }^{37}$ Fichte, Das System der Rechtslehre, p. 633.

38 Fichte, Das System der Rechtslehre, pp. 633-634.

${ }^{39}$ Fichte, Das System der Rechtslehre, p. 633.

40 Philip Pettit has defended a similar thesis inasmuch as he has argued that the civility enables the citizens to develop mechanisms to control the government and the groups of power in order to preserve their rights; Philip Pettit, Republicanism. A Theory of Freedom and Government, New York, Oxford University Press, 2002, pp. 247-269.

41 Fichte, Das System der Rechtslehre, pp. 634-635.

Araucaria. Revista Iberoamericana de Filosofia, Politica, Humanidades y Relaciones Internacionales, año $21, \mathrm{n}^{\circ} 41$. Primer semestre de 2019. Pp. 79-96. ISSN 1575-6823 e-ISSN 2340-2199 doi: 10.12795/araucaria.2019.i41.04 
to believe in a historical progress is a rational faith in the possibility of the historical realization of the supreme good. ${ }^{42}$ That is to say, the agent must suppose that history tends to a constant expansion of relationships based upon freedom. Against James, I consider that Fichte actually states that history has a real progressive dynamic. It is for this reason that Fichte argues that we are wrapped up in this process and because of that we have our freedom of action restricted in some sense.

This can be seen clearly in Fichte's diagnosis of his epoch. Fichte definitively believes that he lives in the third epoch. Therefore he considers that right can only hope for an efficient regulation of the interactions between rational egoists. This means that Fichte does not deem possible an effective control of the government, given that the epochal horizon hinders the moral formation of virtuous citizens. This conviction leads Fichte to consider Napoleonic imperialism as the highest point of his epoch, marked by selfishness and materialism, as well as by the unbridled grasping for power.

From my viewpoint, Fichte tries to reconstruct in his texts of philosophy of history the way in which humanity actually arrived at the current cultural and moral situation. He wants to make intelligible the causes that give a genealogical sense to the challenges he had to face. Nevertheless, Fichte articulates a reasoned conception of the whole historical path, which opens in turn an optimistic perspective of the future. In relationship to the future, Fichte does not endorse a deterministic conception but concludes that certain possibilities of action are left open. However, the effective realization of a future of freedom and peace for humanity depends on the decisions that persons make in each case. As we shall see bellow, the education in the Doctrine of Knowledge, as well as the development of the art of governing will make possible a positive outcome for our human race. That means that Fichte trusts in the possibility of the development of rationality in history. My hypothesis is that Fichte trusts in the idea that the historical progress will put the necessary conditions in order for the people to choose their government wisely. In order to unravel this argumentative moment, I think that it is necessary in the first place to take into account the philosophy of history, which is at the base of the Fichtean theory.

\section{The Idea of an Absolute State and the Culmination of History}

Fichte develops his conception of history in The Characteristics of the Present Age, a series of conferences given between 1804 and 1805 but published in 1806 . The text begins with the establishment of the ultimate aim

\footnotetext{
${ }^{42}$ David James, Fichte's Republic. Idealism, History and Nationalism, Cambridge, Cambridge University Press, 2015, pp. 90, 92, 94-95, 105.
}

Araucaria. Revista Iberoamericana de Filosofía, Política, Humanidades y Relaciones Internacionales, año $21, \mathrm{n}^{\circ} 41$. Primer semestre de 2019. Pp. 79-96. ISSN 1575-6823 e-ISSN 2340-2199 doi: 10.12795/araucaria.2019.i41.04 
of the human species, which is the axis that makes sense of history. This aim is that humanity structures their relationships using reason and acting freely. ${ }^{43}$

As a consequence, Fichte arrives at the concept of a plan of the universe, which structures all epochs through a rational deduction of each of them from the final state toward which humanity must strive. ${ }^{44}$ In summary, the plan of the universe for humanity consists of five epochs. Given that the ultimate aim of humanity is to self-govern rationally, there necessarily must have been a first epoch in which rationality was present, though inchoately. The reason for that is that nothing can result from nothing, and, therefore, rationality cannot be the result of a complete irrationality. In this first epoch, reason rules through rational instinct ("the state of the innocence of the human race", der Stand der Unschuld des Menschengeschlechts).

It is followed by a second epoch, in which the rational instinct is imposed by a group of rulers on the subjects and is called "the epoch of the inchoate sinfulness" (der Stand der anhebenden Sünde). The reason for this transition to the second epoch is that human beings need a certain social organization in order to meet their needs. However, given that human beings are still under the influence of the moral instinct, they cannot know the grounds of their rational beliefs, so they must be imposed by force. Therefore, human beings must submit coactively so that they obey the government.

Nevertheless, along the path of growing in rationality and freedom, human beings will inevitably rebel against those authorities who impose rational truths by force and without the subjects knowing their grounds. Fichte deems that the current epoch is the third historical epoch. The reason for that is that the liberation of the rational instinct takes place in the third epoch, which is present coactively in the ruling classes of the second epoch. Fichte calls the third epoch "the epoch of the complete sinfulness" (der Stand der vollendeten Sündhaftigkeit). The meaning of this name is that the individual, while rebelling against the rational instinct, does so against reason in general and truth itself. ${ }^{45}$ On the other hand, given that this rebellion is directed against the blind obedience of the mandates, the individual remains satisfied with that

${ }^{43}$ „Der Zweck des Erdenlebens der Menschheit sey der, dass sie in demselben alle ihre Verhältnisse mit Freiheit nach der Vernunft einrichte (...)“; Johann Gottlieb Fichte, Grundzüge des gegenwärtigen Zeitalters, Das System der Rechtslehre, in Fichtes Sämtliche Werke, ed. Immanuel Hermann Fichte, Berlin, Walter de Gruyter, 1971, Volume VII, p. 7.

${ }^{44}$ Herder had criticized the historical teleological determinism, pointing out to the role which there is played by the hazard; Johann Gottfried Herder, Auch eine Philosophie der Geschichte zur Bildung der Menschheit, Stuttgart, Reclam, 2007, pp. 36-38, 56-57, 83-84. Berlin states that in the last instance Herder falls in a historical relativism; Isaiah Berlin, Vico and Herder. Two Studies in the History of Ideas London, Chatto \& Windus, 1980, pp. 210-211. On the contrary, Wood argues that Herder aims at making true judgments in respect to the way in which each culture developed itself; Allen Wood, The Free Development of Each: Studies on Freedom, Right and Ethics in Classical German Philosophy, Oxford: Oxford University Press, 2014, p. 128.

45 Fichte, Grundzüge, p. 18.

Araucaria. Revista Iberoamericana de Filosofia, Política, Humanidades y Relaciones Internacionales, año $21, \mathrm{n}^{\circ} 41$. Primer semestre de 2019. Pp. 79-96. ISSN 1575-6823 e-ISSN 2340-2199 doi: 10.12795/araucaria.2019.i41.04 
which can be conceived clearly. In this sense, the third epoch is a mediation to the fourth one.$^{46}$ Nevertheless, the individual in the current epoch conceives the world from his or her need to subsist, for which he or she has after all the purpose of maximizing the technical quality of adequate tools ${ }^{47}$ Therefore, the actions of altruists are disqualified as naïve and irrational. ${ }^{48}$

In the fourth epoch, humanity develops and internalizes rational science (die Epoche der Vernunftwissenschaft). Finally, on the horizon of history there is the image of a humanity that organizes their relationships rationally and freely. This is the fifth epoch, or the "epoch of the complete justification and sanctification" (der Stand der vollendeten Rechtfertigung und Heiligung). ${ }^{49}$ This means humanity in this final epoch must be provided with the art of acting rationally. According to Fichte, the individual acts rationally when he or she sacrifices his or her individuality in pursuit of the unity of the human species. ${ }^{50}$ The reason for that is that individuals are mere appearances of the only and universal reason, which must manifest itself necessarily in the form of the human species, that is, as divided into several individualities. ${ }^{51}$ The rational life manifests itself as a love for itself inasmuch as the individual feels approbation, respect, and veneration for this ideal. In this sense, the individual develops the love for the rational life, which is self-reliant and is the most perfect form of happiness. ${ }^{52}$

Besides, the idea of state that Fichte deems must have been established in the last epoch of history is considerably different from the one he developed in the Foundations of Natural Right. Fichte states that the culmination of human progress must take place in the "absolute state" ${ }^{53}$ The absolute state is a product of a rational art, which presupposes that the individuals have grasped and internalized the central elements of the science of knowledge (which can take place only in the fourth epoch). Thence, the state, from the formal viewpoint, has the function of coercing the individuals to direct their forces to the ultimate aim of the human species. Nevertheless, the content of this ultimate aim has to be established. In other words, the matter of the absolute state must be determined. The ultimate aim of the human species is the subsistence of human beings in order to promote the development of culture. For this reason, the matter of the absolute state is the guarantee of this fundamental good. ${ }^{54}$

${ }^{46}$ Fichte, Grundzüge, pp. 20-21.

${ }^{47}$ Fichte, Grundzüge, p. 26; Alexander Aichele, "Ending Individuality: The Mission of a Nation in Fichte's Addresses to the German Nation", in The Cambridge Companion to Fichte, eds. David James and Günther Zöller (Cambridge: Cambridge University Press, 2016), pp. 258-259.

${ }^{48}$ Fichte, Grundzüge, pp. 29-31.

${ }^{49}$ Fichte, Grundzüge, pp. 11-12.

${ }^{50}$ Fichte, Grundzüge, pp. 34-35, 37.

${ }^{51}$ Fichte, Grundzüge, pp. 22-26.

${ }^{52}$ Fichte, Grundzüge, pp. 39-41, 56-58.

${ }^{53}$ Fichte, Grundzüge, p. 144.

${ }^{54}$ Fichte, Grundzüge, pp. 145-147.

Araucaria. Revista Iberoamericana de Filosofia, Política, Humanidades y Relaciones Internacionales, año $21, \mathrm{n}^{\circ} 41$. Primer semestre de 2019. Pp. 79-96. ISSN 1575-6823 e-ISSN 2340-2199 doi: 10.12795/araucaria.2019.i41.04 
Even though some individuals play the role of government, that is, of directing the forces of the others, Fichte actually defends a relatively strict egalitarianism. ${ }^{55}$ Although the citizens put their forces at the service of the state, they are all sovereign, because they have to make the state remember the aim it has to pursue. ${ }^{56}$ On the other hand, this egalitarianism is expressed in the requirement that all citizens receive the product of their effort in the form of basic social rights. ${ }^{57}$ Furthermore, the popular classes must be freed from the obligation to satisfy the whims of the dominant classes, because they must use their forces to contribute to the common good. ${ }^{58}$

\section{Final Remarks}

The philosophy of history of 1804 and 1805 enables Fichte to place his natural right developed previously in Jena against a diachronic background. As such, Fichte does not reason merely synchronically from a timeless conception of society and state. From a synchronic viewpoint, Fichte cannot solve the problem of the control of political power, because he has to draw on the assumption of a virtuous ephorate. As it was argued, this assumption is not consistent with the Fichtean ideal of a philosophy of right completely independent from moral considerations. Thus, the control of government is possible only if at least a group of citizens can go beyond mere rational egoism.

Meanwhile, it can be argued that Fichte in his Berliner period takes account of the historicity of social processes and political structures. Following this line of reasoning, it is possible to state that Fichte adopts a diachronic viewpoint where he can place the systematic problems of his previous theory against the background of a historical process. This new temporal conception of the state leads Fichte to think that the problems of consistency of his theory of Jena are unavoidable, given that a society integrated by egoist individuals cannot be sustained. However, his later philosophy of history enables Fichte to state the inexorable annihilation of this type of community that gives place to an ensuing epoch when the citizens are not self-interested anymore.

This is the last epoch of humanity in which the development of the absolute state takes place. As has been argued, the citizens must have had access to a moral and philosophical formation that must have enabled them to exercise reason in order to know the supersensible world. Against the background of this new political and legal frame, Fichte aims at solving the problem of control of political power and of the stability of the submission contract. Besides, Fichte

\footnotetext{
${ }^{55}$ Fichte, Grundzüge, pp. 160-161.

${ }^{56}$ Fichte, Grundzüge, pp. 152-153.

${ }^{57}$ Fichte, Grundzüge, pp. 157-159.

58 Fichte, Grundzüge, pp. 207-209.
}

Araucaria. Revista Iberoamericana de Filosofia, Politica, Humanidades y Relaciones Internacionales, año $21, \mathrm{n}^{\circ} 41$. Primer semestre de 2019. Pp. 79-96. ISSN 1575-6823 e-ISSN 2340-2199 doi: 10.12795/araucaria.2019.i41.04 
can also give an account of the role that the moral civic education plays in order to fulfil the protection contract. This means that Fichte understands that he can give stability to his theory of right only from an ideal of citizenship in which virtue has a central place. Thus, Fichte moves the solution to the systematic problems posed by his philosophy of right from Jena to a later epoch, where the culmination of history will take place.

My hypothesis is that this temporal conception of the state comes from the evaluation by Fichte of the political, cultural, and moral crisis of the German nation he witnesses. After carrying out this analysis, Fichte deems in The Characteristics of the Present Age that he is living in the third epoch. Three years later, Fichte notes that the situation has worsened and Germany has arrived at a cutoff point of decadence. From the Fichtean viewpoint, this has led the nation to the threshold of the fourth epoch. ${ }^{59}$ The German government has fallen into ease and laziness and has not taken care to enforce the law and to exercise its authority over its subjects. ${ }^{60}$ As a consequence, the Germans have fallen into the hands of the Napoleonic forces. Fichte thinks that the French are a barbaric and individualist people from their very origin, whose highest exemplar is Louis XIV. They rebelled in order to break the chains that enslaved them but were deceived by Napoleon, who promised them their freedom. ${ }^{61}$ France, the enemy of Germany in this war, is driven only by the frantic search for power and richness and is willing to subdue the other countries with terror. ${ }^{62}$ Therefore, the Napoleonic Empire means for Fichte the exacerbation and culmination of the third epoch and its extreme egoism.

While in the natural right, Fichte built a theory of right based upon the right to coercion; now he deems it unsustainable. The reason for that is that the egoism of the government and its indolence when having to apply the law produced an atmosphere of lawlessness. This situation broke the bond that unified the people with their government, which was based upon fear and hope, namely, rational egoism. ${ }^{63}$ This means that Fichte in his natural right of Jena stated that the citizens could at least behave as rational egoists, i.e., they will maximize their preferences, even though between the limits set by the law. In other words, the egoism of the citizens could be restricted at least by the fear of

59 Johann Gottlieb Fichte, Reden an die deutsche Nation, Die Staatslehre oder über das Verhältnis des Urstaates zum Vernunftreiche, in Fichtes Sämtliche Werke, ed. Immanuel Hermann Fichte, Berlin, Walter de Gruyter, 1971, Volume VII, pp. 264-265. For this reason, Reiß defines the third epoch as a "null point" (Stunde Null), placed between the disappearance of the ancient world and the rise of the new one in the form of the fourth epoch; Stefan Reiß, Fichtes 'Reden an die deutsche Nation', Berlin, Akademie Verlag, 2006, 26.

${ }^{60}$ Fichte, Reden an die deutsche Nation, pp. 270-271.

61 Johann Gottlieb Fichte, Die Staatslehre oder über das Verhältnis des Urstaates zum Vernunftreiche, in Fichtes Sämtliche Werke, ed. Immanuel Hermann Fichte, Berlin, Walter de Gruyter, 1971, Volume IV, p. 424.

${ }^{62}$ Fichte, Die Staatslehre, p. 427.

${ }^{63}$ Fichte, Reden an die deutsche Nation, pp. 272-273, 283-284. 
losing their freedom and property as a consequence of violating the law. Fichte assumed then that an egoist citizen could be prudent enough to recognize the restrictions set by the penal law and act according to them. In other words, Fichte assumed a moral psychology according to which the prevision of the negative consequences for one's own preferences could restrict the actual behavior. For this reason, egoism had its own limit, and there was no danger of it becoming unbridled.

On the contrary, in his later texts, Fichte notes that education has produced in the German people a reckless and destructive egoism. The aim of education has been, above all, the instrumental utility of what is learned. Thus, the citizens have been aiming only at maximizing their advantages. This conception of subjectivity has produced such corruption that it is not possible to make a constructive use of the citizens' self-interest anymore. ${ }^{64}$ Therefore, the moral-psychological foundations of the Fichtean theory of natural right have disappeared, and the philosophical developments of 1796 and 1797 must be revised. It is for this reason that Fichte undertakes such a decisive reformulation of not a few of the aspects of his political theory.

Therefore, Fichte states in his Addresses to the German Nation that the people must be educated in order to develop an attitude of abhorrence toward the dishonorable, petty, and egoist behavior. Thus, the people will try to do their best to correct this type of situation. ${ }^{65}$ For that purpose, it is necessary to eliminate the distinction between the estate of the scholars and the people trained for manual labor. In other words, the literary and philosophical formation is not to be the privilege of a few but must be an obligation for all the people. This explains the requirement of a public formation of a humanistic type, which must develop in the citizens the faculty to know the supersensible world and to love philosophical research. Only in that way could the entire people be educated in the love for justice, the feeling of duty, and the love for fatherland. ${ }^{66}$

As a result of this process, the people must be capable of forming by themselves the image of a new nation to be built. ${ }^{67}$ Along this line, the Germans are a privileged people because their language enables them to know the supersensible in analogy with the everyday sensible world. ${ }^{68}$ This means that

${ }^{64}$ Fichte, Reden an die deutsche Nation, pp. 289-290, 428-431.

${ }^{65}$ Fichte, Reden an die deutsche Nation, pp. 273-274.

${ }^{66}$ Fichte, Reden an die deutsche Nation, pp. 276-277, 280-281 384-385, 419-421. This is a central debate for the tradition of the Bildung; Frederick Beiser, "A Romantic Education. The Concept of Bildung in early German romanticism", in Philosophers on Education, ed. Amélie Oksenberg Rorty, London / New York, Routledge, 2003, p. 289.

${ }^{67}$ Fichte, Reden an die deutsche Nation, pp. 284-285. This thesis is in line with the tradition of the Bildung, which comes from the concept of self-formation coined by Shaftesbury; Reinhardt Koselleck, Begriffgeschichten. Studien zur Semantik und Pragmatik der politischen und sozialen Sprachen, Frankfurt, Suhrkamp, 2006, p. 109.

${ }^{68}$ Fichte, Reden an die deutsche Nation, pp. 315-318, 327, 331-332. In this point, Reiß notes the influence of August Wilhelm Schlegel (Reiß, Fichtes ,Reden an die deutsche Nation', pp. 120-124).

Araucaria. Revista Iberoamericana de Filosofia, Politica, Humanidades y Relaciones Internacionales, año $21, \mathrm{n}^{\circ} 41$. Primer semestre de 2019. Pp. 79-96. ISSN 1575-6823 e-ISSN 2340-2199 doi: 10.12795/araucaria.2019.i41.04 
German is the only language that can enable us to know the metaphysical world and moral ideals. Therefore, only the Germans can conceive the ideal of a just nation. ${ }^{69}$

For the former reasons, Fichte opposes the mechanical idea of the state, which is meant to work as a machine by the coercion of the citizens, who will obey the law for fear of losing their freedom and property. ${ }^{70}$ Against the background of this mechanical idea of the state, coercion cannot come from the people because they could not force themselves to perform an action or to punish themselves. The reason for that is that if the people agree with what is prescribed by the norm, they would not need to compel themselves to obey it. However, the people neither agree with the norm nor could force themselves to fulfil it, given that they have the power to resist such a coercion by themselves, the people being the subject who is applying it to themselves.

Against the background of this mechanical conception of the state, coercion must be exerted by the government in order for the system to be selfsustainable. This means that the government is able to compel the people but cannot force itself for the same reason the people cannot do so. Therefore, this conception of the state is based upon the hazard that the government is virtuous. ${ }^{71}$ Hence, it is an unstable conception of the political government. As was concluded before, Fichte rejects even the idea of the ephorate, which plays a central role in his theory of 1796 and 1797, because it is grounded in this assumption. Against this mechanical and hazardous ideal of the state, Fichte comes up with the education of the people in virtue in order to give stability to his theory. ${ }^{72}$ In other words, an educated people are the only effective control of a centralized government, because they do not exert a direct coercion against the authorities but submit them to constant surveillance. In summary, Fichte concludes the necessity to overcome the mere legal state (Rechtsstaat) in order to establish the cultural state (Kulturstaat).

\footnotetext{
${ }^{69}$ However, as Bloch points out, Fichte does not stand for a closed and aggressive nationalism, given that the nation is not something given but an ideal meant to be freely built. On the other hand, the nation is not closed in itself unit but a mediation between the individual and the human species. This means that authentic patriotism leads to orient one's own nation in a cosmopolitan way; Ernst Bloch, ,Fichtes Reden an die deutsche Nation (1943)”, pp. 300-303.

70 James states that this conception can be tracked back to the moral psychology developed by Helvétius in De l'esprit; James, Fichte's Republic, pp. 100-102.

71 Fichte, Reden an die deutsche Nation, pp. 364-366.

72 The idea of the state as a Bildungsanstalt ("educative institution") has played an important role in the debates about the Bildung, in the case of authors like Schleiermacher, Novalis, and Schiller; Beiser, “A Romantic Education”, p. 291.
} 


\section{Bibliography:}

Aichele, Alexander, "Ending Individuality: The Mission of a Nation in Fichte's Addresses to the German Nation", in The Cambridge Companion to Fichte, eds. David James and Günther Zöller (Cambridge: Cambridge University Press, 2016), pp. 248-272.

Frederick Beiser, "A Romantic Education. The Concept of Bildung in early German romanticism", in Philosophers on Education, ed. Amélie Oksenberg Rorty, London / New York, Routledge, 2003, pp. 284-299.

Berlin, Isaiah, Vico and Herder. Two Studies in the History of Ideas London, Chatto \& Windus, 1980.

Bloch, Ernst, „,Fichtes Reden an die deutsche Nation (1943)“, (in Werkausgabe.

Band 11. Politische Messungen, Pestzeit, Vormärz, Frankfurt am Main, Suhrkamp, 1985), pp. 300-312.

Fichte, Johann Gottlieb, Foundations of Natural Right, trans. Michael Baur, ed. Frederick Neuhouser, New York, Cambridge University Press, 2000

Fichte, Johann Gottlieb, Grundlage des Naturrechts nach Prinzipien der Wissenschaftslehre, Jena and Leipzig, Christian Ernst Gabler, 1796/179. It is quoted according to Johann Gottlieb Fichte: Gesamtausgabe der Bayerischen Akademie der Wissenschaften, ed. Reinhard Lauth and Hans Jacob, Stuttgart-Bad Cannstatt, Frommann Verlag, Günther Holzboog, 1966, with the volume and page number.

Johann Gottlieb Fichte, Die Staatslehre oder über das Verhältnis des Urstaates zum Vernunftreiche, in Fichtes Sämtliche Werke, ed. Immanuel Hermann Fichte, Berlin, Walter de Gruyter, 1971, Volume IV.

Johann Gottlieb Fichte, Reden an die deutsche Nation, Die Staatslehre oder über das Verhältnis des Urstaates zum Vernunftreiche, in Fichtes Sämtliche Werke, ed. Immanuel Hermann Fichte, Berlin, Walter de Gruyter, 1971, Volume VII.

Fichte, Johann Gottlieb, Das System der Rechtslehre, in Fichtes Sämtliche Werke, ed. Immanuel Hermann Fichte, Berlin, Walter de Gruyter, 1971, Volume X.

Geismann, Georg, „Fichtes ,Aufhebung“ des Rechtsstaates“, Fichte- Studien. Band 3. Sozialphilosophie, Amsterdam, Atlanta: Editions Rodopi, 1991, pp. 86-117.

Hegel, Georg Wilhelm Friedrich, Über die wissenschaftichen Behandlungsarten des Naturrechts, seine Stelle in der praktischen Philosophie und sein Verhältnis zu den positiven Rechtswissenschaften; in: Kritisches Journal der Philosophie, Bd. II, Part 2, [November/December] 1802, Part 3, [May/June] 1803. Quoted according to the edition: G.W.F. Hegel: Werke in 20 Bänden; Frankfurt am Main, Suhrkamp Verlag 1970, Volume 2. 
Herder, Johann Gottfried, Auch eine Philosophie der Geschichte zur Bildung der Menschheit, Stuttgart, Reclam, 2007.

James, David, Fichte's Republic. Idealism, History and Nationalism, Cambridge, Cambridge University Press, 2015.

Reinhardt Koselleck, Reinhardt, Begriffgeschichten. Studien zur Semantik und Pragmatik der politischen und sozialen Sprachen, Frankfurt, Suhrkamp, 2006.

Pettit, Philip, Republicanism. A Theory of Freedom and Government, New York, Oxford University Press, 2002.

Rei $\beta$, Stefan, Fichtes 'Reden an die deutsche Nation', Berlin, Akademie Verlag, 2006.

Renaut, Alain Le Système de Droit. Philosophie et droit dans la pensée de Fichte, Paris, Presses Universitaires de France, 1986.

Schottky, Richard, „Rechtsstaat und Kulturstaat bei Fichte. Eine Erwiderung“, Fichte-Studien. Band 3. Sozialphilosophie, Amsterdam, Atlanta: Editions Rodopi, 1991, pp. 118-153.

Siep, Ludwig, "Revolution, Nation und Individuum in Fichtes philosophischer Entwicklung" in Fichte-Studien. Band 44. Beiträge zur Geschichte und Systematik der Transzendentalphilosophie, ed. Marco Ivaldo, Leiden: Brill Rodopi and Hotei Publishing, 2017, pp. 141-151.

Stolzenberg, Jürgen, "Fichtes Begriff des praktischen Selbstbewusstseins" (in Wolfram Hogrebe, Fichtes Wissenschaftslehre. 1794. Philosophische Resonanzen, Frankfurt am Main, Suhrkamp, 1995), pp. 71-95.

Wood, Allen, The Free Development of Each: Studies on Freedom, Right and Ethics in Classical German Philosophy, Oxford: Oxford University Press, 2014.

Wood, Allen, "Fichte's Philosophy of Right and Ethics" (in The Cambridge Companion to Fichte, eds. Gunther Zöller and David James, Cambridge: Cambridge University Press, 2016), pp. 168-198. 